\title{
INTRODUCTION TO THE PRETORIA STUDENT LAW REVIEW: SPECIAL EDITION ON THE DECOLONISATION AND AFRICANISATION OF LEGAL EDUCATION
}

by Annette Lansink* \& Ademola Oluborode Jegede**
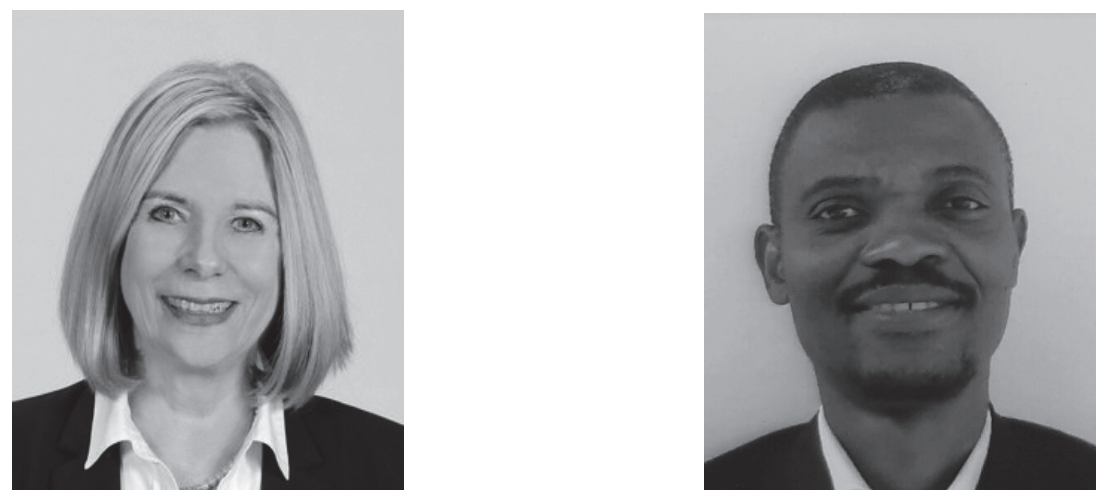

\section{Introduction}

This special edition of the Pretoria Student Law Review (PSLR) is devoted to papers presented at a Conference on Decolonisation and Africanisation of Legal Education hosted by the University of Venda and the South African Law Deans Association (SALDA). ${ }^{1}$ This was the third event on decolonisation and Africanisation under the umbrella of SALDA in the period 2016 to 2019 and the first devoted to law students.

The reason is not farfetched. While the movement to transform and decolonise higher education has since been on the ascendancy in South Africa, the intellectual voice of law students who are at the centre as both the recipients and the future agents of the discourse is faint. Thus, the purpose of the law student conference was to listen to the perspectives of students and intellectually engage the various meanings and implications of decolonisation and Africanisation of legal education. The conference was premised on the fact that, although postcolonial and post-apartheid legal education in South

* $\quad$ Annette Lansink (former Dean: School of Law, University of Venda).

** Ademola O Jegede (Professor of Law, University of Venda).

1 Law Students' Conference on the Decolonisation and Africanisation of Legal Education (2019) University of Venda, Thohoyandou. 
Africa has seen many changes, the knowledge systems in the legal discipline remain rooted in colonial and western worldviews and epistemological traditions. The Conference held at the University of Venda on 15 July 2019 was attended by students and staff members from 15 out of the 17 South African law faculties.

We are indebted to Prof Tshepo Madlingozi for giving an insightful and much appreciated keynote address that set the tone of the conference by raising critical questions. Prof Madlingozi posed five 'provocations', to wit the possibility of decolonising the curriculum in a colonised university, the need to address institutional racism and its manifestations in the hidden curriculum, the meaning of moving beyond the ivory tower, the necessity to link up with social movements, the importance of critical pedagogy as well as multi- and transdisciplinarity, and the need to develop our own norms and not to borrow uncritically from Latin-American and African-American experiences. In his address, Prof Madlingozi argued for a postconquest constitution that recognises pluriversalities and emphasised the point that colonialism and coloniality should be made the unit of analysis. He also contended that decoloniality will be disruptive and should not be equated with mere transformation.

The first article in this collection is by Mankhuwe Letsoalo and Zenia Pero on Historically white universities and the white gaze: critical reflections on the decolonisation of the LLB curriculum which takes the point of distinguishing decolonisation from transformation further. The article critically reflects on the University of Pretoria's Curriculum Transformation Framework document in which the University identified four drivers of curriculum transformation (responsiveness to social context; epistemological diversity; renewal of pedagogy and classroom practices; and an institutional culture of openness and critical reflection) as an essential tool in decolonising legal education, especially in white universities as it provides indepth strategies to achieve epistemic justice. The authors, however, caution against an approach that fails to confront whiteness and deep-rooted legacies of racial exclusion and cultural domination at universities. Following in the footsteps of the philosopher George Yancy, the article employs the term 'white gaze' which 'encapsulates black experiences in white spaces' as a site of power and control that structures 'how race operates socially and epistemologically'. According to Yancy, the white gaze is a 'form of embodied seeing'. The authors emphasise the need to dismantle whiteness within the institutional culture otherwise decolonisation runs the risk of denoting change at historically white universities and merely 
incorporating African concepts into an Eurocentric educational system.

The title of the article by Ropafadzo Maphosa and Nomathole Nhlapo is Transformative legal education in the South African context. This article starts with examining the impact of the disparities brought about by apartheid in the provision of legal education, inter alia, the lack of resources at historically black universities, and the geographical restrictions placed on black law graduates. In the next section, the history of the four-year LLB is discussed in the light of transformation objectives. The authors proceed to engage Himonga and Diallo's three aspects of decolonisation: the integration of living customary law in law modules; a shift in the theoretical paradigm within which law is taught, and the importance of an interdisciplinary study of law in the African context using the methods and insights from the social sciences and comparative law to elucidate the understanding of law in its broader societal context. ${ }^{3}$ Maphosa and Nhlapo propose that fundamental concepts in law be taught less axiomatically and more critically, and advocate for a 'therapeutic jurisprudence'. While embracing the constitution, they make an argument for the 'redesign' of legal education and the infusion of African and constitutional values so that ultimately the legal order 'mirrors the society' in which it exists.

In Decolonising legal education in South Africa: a review of African indigenous law in the curriculum, Joshua Mawere grounds arguments on decolonisation in the theory of Afrocentricity. After providing several definitions of the latter, including from Molefi Asante, ${ }^{4}$ Mawere advocates for a paradigm shift in the law curriculum to respond to the needs of Africans. He examines how colonialism led to epistemicide and endorses Ngũgĩ wa Thiong'o's view on the direction that the education system should take to break with neocolonialism. ${ }^{5}$ Ngũgĩ wa Thiong'o argues for decolonisation of the mind, a liberation from colonial education and the 'consciousness necessarily inculcated in the African mind' by the inherited colonial education system; at the heart of this struggle for control and political, economic and cultural self-definition are African languages. ${ }^{6}$ To foreground knowledge from an African point of view, Mawere suggests introducing 'living indigenous law' in the law curriculum. This needs to be distinguished from the 'old' indigenous

3 C Himonga \& $\mathrm{F}$ Diallo 'Decolonisation and teaching law in Africa with special reference to living customary law' (2017) 20 Potchefstroom Electronic Law Journal 3.

4 See MK Asante Afrocentricty: The theory of social change (2003); The Afrocentric idea (1998).

5 Ngũgĩ wa Thiong'o Decolonising the mind: The politics of language in African literature (1981) Zimbabwe Publishing House (1987) 101.

6 Ngũgĩ (n 5 above) 101, 108, 4. 
law which has been tainted by colonialism whereas living indigenous law is situated in the 'social actualities within which people live their lives'. He supports the critical views of Joel Modiri and Tshepo Madlingozi regarding the South African Constitution and how it is 'implicated' in the failure to address the 'structural continuity' of apartheid and colonialism. ${ }^{7}$ As a way forward, the author asserts the importance of centring indigenous law and values in the entire law curriculum, an interdisciplinary and multicultural approach to the law, African teachers and a syllabus that includes both African and European views and knowledges.

The next article is by Paul Mudau and Sibabalo Mtonga Extrapolating the role of transformative constitutionalism in the decolonisation and Africanisation of legal education in South Africa. The authors focus on transformative constitutionalism and contend that the University of Pretoria's Transformation document with its four drivers contains valuable guidelines for curriculum transformation that 'resonates well with the objectives of both the National LLB Standard and transformative constitutionalism itself'. The authors consider views on decolonisation and decoloniality from both African and Latin-American scholars, including Motshabi, Mignolo and Maldonado-Torres and highlight the need to decolonise the mind and knowledge itself as well as the inadequacy of Western theories to solve local problems. ${ }^{8}$ The article considers various perspectives on decolonisation, including an 'inside-out vision from Africa into the world' with a focus on Africa and its people, while subscribing to the view that there is not a 'single one-dimensional answer'. African epistemology and African practices are embraced whereby African jurisprudence has precedence over European knowledge systems. At the same time, an argument is put forward by the authors to entrench transformative constitutionalism in the curriculum as this 'can enhance' decolonisation and Africanisation of legal education. In the absence of a national pedagogical framework to steer the transformation and decolonisation process, the authors propose using the four drivers contained in UP's Transformation document as a guide.

7 See J Modiri 'Conquest and constitutionalism: first thoughts on an alternative jurisprudence' (2018) 34(3) South African Journal on Human Rights 300; T Madlingozi 'Social Justice in a time of neo-apartheid constitutionalism: critiquing the anti-black economy of recognition, incorporation and distribution (2017) 28(1) Stellenbosch Law Review 123.

8 See KB Motshabi 'Decolonising the university: a law perspective' (2018) 40(1) Strategic Review for Southern Africa 104; MW Mignolo 'Delinking: the rhetoric of modernity, the logic of coloniality and the grammar of de-coloniality (2007) 21 (2-3) Cultural Studies 459; N Maldonado-Torres 'Thinking through the decolonial turn: post-continental interventions in theory, philosophy, and critique - an introduction' (2011) (1) Transmodernity: Journal of Peripheral Cultural Production of the Luso-Hispanic World 1 
In Breaking the language barrier in legal education: a method for Africanising the LLB curriculum, Thokozani Dladla examines the relationship between law and language in the light of section 6(2) of the Constitution and the failure to advance multilingualism in the LLB curriculum. The author argues that despite the constitutional imperative on the state to take positive measures to advance the historically diminished use and status of indigenous languages, the use of African languages in law has not been promoted while the first language of the majority of South Africans is an African language. It is for this reason that Dladla critically engages the lack of transformation in this regard and the 2017 directive to judicial officers by the Chief Justice in which English was declared the only language of record in South African courts. Drawing upon the Constitution and case law, an argument is put forward that noninclusion of compulsory African languages in legal education and the non-promotion of African languages in government policies where it is reasonably practical to do so would amount to unfair discrimination. The author proposes that at least one African language be made compulsory in the LLB curriculum and further that each law school chooses an African language of the region and 'partner with schools of languages to translate sources of law'. Translating legal texts in African languages will deepen understanding and enhance multilingualism while the teaching of law modules and, ultimately the entire LLB curriculum, in a local African language would be to the benefit of law students, the legal profession and society at large. At the same time, it will enhance efficiency in courts and the sociological context of law in particular for non-African language speakers.

In the penultimate article on the topic Critical legal education: $a$ remedy for the legacy of colonial legal education, Emerge Masiya and Given Mdluli use Critical Legal Studies (CLS) to deconstruct the law and colonial epistemology. They recommend the replacement of a colonial "black-letter" approach to law and teaching, formalism and a restrictive jurisprudence with a 'therapeutic jurisprudence'. They suggest that legal naturalism which according to them is more in line with 'traditional African legal phenomena' be substituted for legal positivism. The authors combine insights from CLS with the approach advocated by Himonga and Diallo ${ }^{9}$ to advocate for alternative epistemologies with a view to promoting 'the transformative potential of law in achieving social and economic justice'. Following Modiri they criticise the formalistic and text-book conscious legal culture, and suggest a 'policy-oriented consequentialist approach' instead of a functionalist one. Masiya and Mdluli contend that CLS is most suitable as a vehicle for decolonising the law due to its 
'restorative, cosmopolitan outlook and interdisciplinary approach' and ability to enhance the inclusion of African values such as ubuntu.

In the last article in this collection titled Decolonisation of the law curriculum in South Africa through the prism of a lived experience, Mandisi Magula and Shatadi Phoshoko, set out to show the historical context of colonialism and its impact on the law curriculum. The authors argue for the creation of an Afrocentric curriculum that would be better attuned to the needs of the country than the Eurocentric curriculum currently used in law schools, which produces graduates who are 'blind to the identity and knowledge' of Africans and unable to solve societal problems. They mention some good practices such as the inclusion of modules focused on African philosophy and customary law in the University of South Africa (UNISA) law curriculum and provide examples how the curriculum can become Afrocentric. Their article posits that African languages be prioritised and ubuntu made the 'basic principle' of the law, the latter is premised on the contention by the South African philosopher Mogobe Ramose that ubuntu is the basis of African law. ${ }^{10}$ Hence, the article argues for the inclusion of African knowledge and perspectives to ensure that the law curriculum is decolonised, Africanised and able to serve the needs of society.

The conference provided a forum for the voice of law students in South Africa as students representing all but two law faculties presented papers. After the conference students were asked to prepare their presented papers for publication. Seven papers were finally submitted for publication after having been anonymously reviewed.

While the quality of the articles varies in the level of detail provided to sustain an argument, the articles are interesting and display a diversity of approaches and emphasis. The articles collectively illustrate the need to engage and overhaul what and how we teach. The need to decolonise legal education has been strongly expressed in all the articles and requires further engagement by the sector. We should be mindful of the fact that the students who submitted papers are not representing law students or their associations. These are students who competed to represent their universities at the conference and their interest in the topic and ability to critically reflect on the law curriculum is commended. Each article albeit in different ways makes the point of the disjuncture between the legal order and society and advances the argument that legal education and the legal order serve the needs of society and its people. Whereas some articles are reflecting on the paradigmatic idea of Afrocentricity, and others argue for transformative constitutionalism and the inclusion of African values or perspectives 
in the law curriculum, in all instances the distinct voice of students is heard.

Other common themes include the importance of teaching living customary law, the necessity of including African languages and African jurisprudence, less formalistic and more critical approaches to teaching law, the need to augment critical thinking skills, situating law in its social context and encouraging multi- and interdisciplinarity in the law curriculum.

As guest editors, we are most grateful to all the contributors and the reviewers whose efforts culminated in making this special issue a reality. The students were committed to the project and we are gratified with their determination and enthusiasm to deliver. We also wish to express a word of appreciation to the Editor-in- Chief of the PSLR, Simon Motshweni, and Dr Gustav Muller for their valuable assistance in ensuring the publication of this special edition and the PSLR Editorial Board for providing space for the conference papers in this journal. 